\title{
Fiscal and Monetary Policies in Nigeria: Key Aspects, Performance, and Policy Options
}

\author{
Adesola Ibironke \\ Adekunle Ajasin University, Akungba-Akoko, Ondo State
}

\begin{abstract}
This paper reviews key aspects of Nigeria's fiscal and monetary policies with the aim of examining the performance of the policies. The paper provides a synthesis of key facts and draws policy conclusions which include the following: (i) fiscal policies such as the oil-price-based fiscal rule introduced in 2004 have increased fiscal discipline and reduced fiscal deficit in Nigeria, hence the policies should be maintained; and (ii) compared to the period of direct or controlled monetary policy approach, monetary policy has performed better in Nigeria under the market-based approach introduced in 1993, therefore the latter approach should be maintained.
\end{abstract}

Keywords: Nigerian Economy; Fiscal Policy; Monetary Policy

JEL Classification Numbers: E58, E62, O55

Date of Publication: 2018-10-12

DOI: 10.24297/jssr.v12i2.7309

ISSN: 2321-1091

Volume: 12 Issue: 2

Journal: Journal of Social Science Research

Website: https://cirworld.com

This work is licensed under a Creative Commons Attribution 4.0 International License. 


\section{Introduction}

Nigeria may be summarily described as an oil-driven small open economy. The World Bank classifies the country as a lower middle-income economy. The IMF classifies it as an emerging and developing economy in the World Economic Outlook (WEO) reports. The economy is also classed as a low human development economy based on the Human Development Index (HDI) and Inequality-Adjusted Human Development Index (IHDI) of the United Nations.

The performance of fiscal and monetary policies in Nigeria is affected largely by the specific attributes of the country, key of which are oil dependency and high level of openness. Oil dependency, for example, makes the country's fiscal policy to be affected by challenges such as volatility of oil price, oil-related ethnic conflicts, and the voracity effect which involves channelling of public funds into private pockets by powerful individuals when there are oil windfalls. The high level of openness, caused largely by the liberalization policy of the Structural Adjustment Programme (SAP) introduced in the country in 1986, for example, makes the monetary policy of the economy to be susceptible to international developments such as fluctuations of the world interest rate.

In line with this background, the objective of this paper is to review key aspects of the fiscal and monetary policies of the country, in order to examine the performance of the policies. The paper has findings having vital policy implications. Regarding fiscal policy, the paper finds, for example, that although fiscal deficit has dominance over fiscal surplus in the country's fiscal policy performance, policies such as oil-revenue smoothing involving a stabilization fund working together with an oilprice-based fiscal rule have reduced fiscal deficit, hence the policies should be maintained. Regarding monetary policy, the paper finds, for example, that monetary policy has performed better in the country in the era of market-based monetary policy approach compared to the era of controlled monetary policy approach, implying that the former approach should be maintained.

The remaining part of the paper is structured as follows: Section two examines key aspects of Nigeria's fiscal policy. Thereafter, key aspects of the country's monetary policy are examined in section three. Section four touches on the role of openness and globalization in the performance of fiscal and monetary policies in the country. Finally, section five presents conclusions and policy lessons.

\section{Fiscal Policy in Nigeria}

The Nigeria Federal Ministry of Finance (FMF) is the main authority in charge of fiscal policy in the country. The Ministry is headed by the Minister of Finance who is also called the Coordinating Minister of the Economy. Deriving its power from the Finance Ordinance of the country, the Ministry was created in 1958 for the purpose of controlling and managing the public finance of the economy (FMF, 2015). According to the author, some of the specific functions of the Ministry are:

(i) Preparation of annual budgetary estimates for revenue and expenditure of the national budget. The proposed budget presented by the Ministry must be approved by the legislative arm of the government, then signed into law by the President of the nation, before it can be implemented (Ekeocha, 2012).

(ii) Designing policies relating to fiscal and monetary issues. This function implies that although the Ministry is basically in charge of fiscal policies, its policies are designed to have consonance with monetary policies.

(iii) Monitoring government revenue from oil and non-oil resources. The Ministry basically does this through its fiscal policies and budgetary functions. For example, the Ministry has adopted an oil-pricebased fiscal rule, which is employed by the Ministry in designing the annual budgets (Okonjo-Iweala and Osafo-Kwaako, 2007; Okonjo-Iweala, 2008). 
(iv) Working alongside international organizations such as the World Bank and the International Monetary Fund (IMF) on behalf of the country. For example, the Minister of Finance of the country attends meetings organized by international organizations.

(v) Management of revenue allocations across the tiers of government. The Ministry oversees the allocations of revenue to the federal, state, and local governments of the country through the principles of fiscal federalism, which is discussed in detail in the following section.

\subsection{Fiscal Federalism in Nigeria}

The system of government operating in Nigeria is federalism, which involves power sharing between the federal government, state governments, and local governments. The country has 36 and 774 state and local governments respectively. Therefore, the method of intergovernmental fiscal relations in the country is fiscal federalism, which involves constitutional provision for the fiscal powers and responsibilities of each level of government in relation to expenditures and revenues.

Table 1 presents expenditure assignment for the three tiers of government of the country, while Table 2 presents tax jurisdiction and revenue for the three levels of government. As revealed in Table 1, the central government is in charge of nationally strategic functions like provision of defence, while the local governments are in charge of functions relating to the grass-roots such as the management of land use. The residual power of the state governments indicated in the table refers to functions that are not assigned to the federal government or the local governments. The exclusive power is for the central government to conduct nationally strategic functions, while the concurrent power is for the central and state governments to carry out their shared functions (Akindele et al., 2002).

Regarding revenue, as shown in Table 2, there are revenues that the tiers of government are empowered by the constitution to generate themselves through taxation and there are also taxationbased revenues distributed to them from a common purse. In the table, "law" points to the tier of government that is the source of the power backing the collection of tax, "collection" means the level of government that legally has the responsibility to collect tax, while retention/right to collect points to the tier of government or the account that has the legal right to be the owner or custodian of collected revenue.

The revenues disbursed across the different tiers of government are usually based on a revenue allocation formula (RAF), which consists of two sub-formulae through which funds are distributed from a national account called the Federation Account, namely the horizontal and vertical allocation formulae (Lukpata, 2013; Salami, 2011). The vertical allocation formula indicates the percentages of revenue allocated to the three tiers of government from the Federation Account, while the horizontal formula shows the percentages of revenue allocated to the states and local governments only, based on the initial allocation of the vertical allocation formula.

The RAF was initially based on the recommendations of ad hoc commissions/committees and the approval of the president of the country. Then in 1989 a permanent commission called the Revenue Mobilization, Allocation, and Fiscal Commission (RMAFC) was established to recommend the RAF and deal with other related fiscal matters. In carrying out its functions, the RMAFC is empowered by law to function as an autonomous entity that is not subject to the authority of any other organization. However, it works with relevant government agencies including the FMF as the main authority in charge of fiscal policy in the country (RMAFC, 2015).

The Federation Account is kept by the Central Bank of the country and disbursement from the account to the three tiers of government is by a committee called the Federation Account Allocation Committee (FAAC). Key members of the committee include the Minister of States for Finance (chair), the Accountant General of the country, RMAFC, and the commissioners of finance of the 36 states of the nation (RMAFC, 2015; Lukpata, 2013; Salami, 2011). 
Table 1: Assignment of Expenditure Responsibilities to the Tiers of Government in Nigeria

\section{Federal Only}

Defence

Foreign affairs

International trade including export marking

Currency, banking, borrowing, exchange control

Use of water resources

Shipping, federal trunk roads

Elections

Aviation, railways, postal service

Police and other security services

Regulation of labour, interstate commerce, telecommunications immigration

Mines and minerals, nuclear energy, citizenship and naturalization rights

Social Security, insurance, national statistical system (Census births, death, etc.)

Guidelines and basis for minimum education

Business registration

Price control

Federal-State Shared

Health, Social welfare

Education (post primary/technology)

Culture

Antiquities

Monuments, archives

Statistics, stamp duties

Commerce, industry

Electricity (generation, transmission, distribution) 
Research surveys

\section{States Only}

Residual power, i.e. subject neither assigned to federal nor local government level

\section{Local Governments Only}

Economic planning and development

Health services

Land use

Control and regulation of advertisements, pets, small businesses

Markets, public conveniences

Social welfare, sewage and refuse disposal, registration of births, death, Marriages

Primary, adult and vocational education

Development of agriculture and natural resources

Source: Jimoh, 2003.

Table 2: Nigeria's Tax Jurisdiction and Right to Revenue

\begin{tabular}{|c|c|c|c|}
\hline \multirow[t]{2}{*}{ Tax } & \multicolumn{2}{|c|}{ Legal Jurisdiction } & \multirow{2}{*}{$\begin{array}{l}\text { Retention/Right to } \\
\text { Revenue }\end{array}$} \\
\hline & Law & Collection & \\
\hline Import duties & Federal & Federal & Federation Account \\
\hline Excise duties & Federal & Federal & Federation Account \\
\hline Export duties & Federal & Federal & Federation Account \\
\hline $\begin{array}{l}\text { Mining rents and } \\
\text { royalty }\end{array}$ & Federal & Federal & Federation Account \\
\hline Petroleum profits tax & Federal & Federal & Federation Account \\
\hline Capital gains tax & Federal & State & State \\
\hline $\begin{array}{l}\text { Personal income tax } \\
\text { (apart from the ones } \\
\text { listed below) }\end{array}$ & Federal & State & State \\
\hline $\begin{array}{l}\text { Personal income tax: } \\
\text { armed and police } \\
\text { forces, external } \\
\text { affairs officers, } \\
\text { residents of the } \\
\text { Federal Capital } \\
\text { Territory }\end{array}$ & Federal & Federal & Federal \\
\hline
\end{tabular}




\begin{tabular}{|l|l|l|l|}
\hline $\begin{array}{l}\text { Value added tax } \\
\text { (sales tax before } \\
\text { 1994) }\end{array}$ & Federal & Federal/State & Federal/State \\
\hline Company tax & Federal & Federal & Federation Account \\
\hline Stamp duties & Federal & State & State \\
\hline Gift tax & Federal & State & State \\
\hline $\begin{array}{l}\text { Property tax and } \\
\text { ratings }\end{array}$ & State & State/Local & State/Local \\
\hline Licenses and fees & Local & Local & Local \\
\hline Motor park dues & Local & Local & Local \\
\hline Motor vehicle & State & Local & Local \\
\hline Capital transfer tax & Federal & State & State \\
\hline $\begin{array}{l}\text { Pools betting and } \\
\text { other betting taxes }\end{array}$ & State & State & State \\
\hline Entertainment tax & State & State & State \\
\hline $\begin{array}{l}\text { Land registration and } \\
\text { survey fees }\end{array}$ & State & State & State \\
\hline $\begin{array}{l}\text { Market and trading } \\
\text { license and fees }\end{array}$ & State & Local & Local \\
\hline
\end{tabular}

Source: Salami, 2011; Jimoh, 2003.

\subsection{Fiscal Deficit in Nigeria}

The behaviour of fiscal deficit in Nigeria is largely influenced by oil and the developing nature of the economy. The following three key features are observable in Figure 1 below, which displays fiscal surplus/defict in the country: (i) The relatively high budget-surplus to GDP ratio around the middle of the 1970s, which is associated with the oil boom of the time. (ii) The dominance of fiscal deficit over fiscal surplus. (iii) Fiscal deficit of less than 5\% of the GDP between 2000-2010, implying more fiscal discipline in the sub-period over the previous period. This is likely due to the effects of the stabilization fund and the oil-price-based fiscal rule established in the sub-period. ${ }^{1}$ Another plausible reason for the fiscal discipline is the country's strive to meet the covergence criteria of the proposed West Africa Monetary Zone (WAMZ), which was initially designed to start in the early 2000s. ${ }^{2}$

Furthermore, the comovements in the graphs of Figure 2 below, which displays movements in nominal GDP growth rate and fiscal surplus/deficit in Nigeria, particularly some of the outliers of the graphs, give the perception of procyclicality of fiscal policy in Nigeria, which is a common characteristic of

${ }^{1}$ The oil-price-based fiscal rule is used as a tool of channelling oil revenue into the budget via a benchmark oil price. Excess oil revenue is saved in the stabilization fund when the actual price of the oil market is higher than the benchmark price, while dissaving is done when the actual price is lower than the benchmark price.

${ }^{2}$ Achieving a fiscal deficit of no more than $4 \%$ of the GDP by all the proposing members of the monetary union is one of the convergence criteria of the union. The monetary union was to start in 2003 with the following proposing members: Nigeria, Ghana, Guinea, Sierra Leone, and Gambia. But the starting date has been postponed five times, because the proposing members have not all met the convergence criteria for starting it. The five postponements are: from 2003 to 2005, from 2005 to 2010, from 2010 to 2014, from 2014 to 2015, and from 2015 to 2020. 
fiscal policy in developing countries (Talvi and Végh, 2005). These authors and others (e.g. Lane, 2003; Lane and Tornell, 1998) argue that political economy externalities associated with the diffusion of political power among different authorities may be the key factor causing the procyclicality of fiscal policy. In Nigeria's case, the fiscal federalism adopted by the country, which distributes power between the three tiers of government and multiple organizations and agencies within the different levels of government, can lead to proliferation of authorities that may be "competing" for their shares of national resources. The quest to have the best share of the "national cake" by multiple authorities may put pressure on national resources and cause government expenditure to increase during booms and decrease during recessions.

For example, based on possible implicit rent-seeking motives, the 36 state governments and some individuals in political positions in Nigeria sued the federal government over the illegality of the Excess Crude Account (ECA) established by the latter for the purpose of saving surplus oil revenue during oil booms and dissaving during oil revenue shortfalls (see for examples, This Day Live Newspaper, 2014; Channels TV, 2012). The central argument underlying the alleged illegality is that section 162(1) of the Nigerian constitution indicates that all revenues earned by the federal government, with the exception of certain proceeds from the personal income tax that only the federal government has the right to collect, should be kept only in the Federation Account and not in any other account. The exempted personal income tax proceeds include proceeds from the armed forces of the country, the Ministry of external affairs, the police force, and the residents of the Federal Capital Territory, as shown in Table 2 above. The developments affected the continuity of the building process of the ECA and led to its replacement by a sovereign wealth fund (see Sovereign Wealth Fund Institute, 2015; http://www.swfinstitute.org).

Therefore, the Nigerian Sovereign Investment Authority Act of 2011 was enacted, upon which the establishment of the Nigerian Sovereign Investment Authority (NSIA) is based. The 2011 Act authorizes the NSIA to function as an independent entity to manage Nigeria's Sovereign Wealth Fund, which has three sub-funds jointly owned by the three arms of the government of the country, namely the Future Generations Fund, the Nigeria Infrastructure Fund, and the Stabilization Fund (see Nigerian Sovereign Investment Authority, 2015; http://nsia.com.ng). As the author shows, in line with the names of the three sub-funds, they capture three main purposes: (i) saving for future generations; (ii) infrastructure development; and (iii) protection of the macroeconomy against external shocks associated with the dependence of the country on the export of hydrocarbons, particularly crude oil.

Figure 1: Fiscal Surplus/Deficit in

\section{Nigeria (1970-2010)}

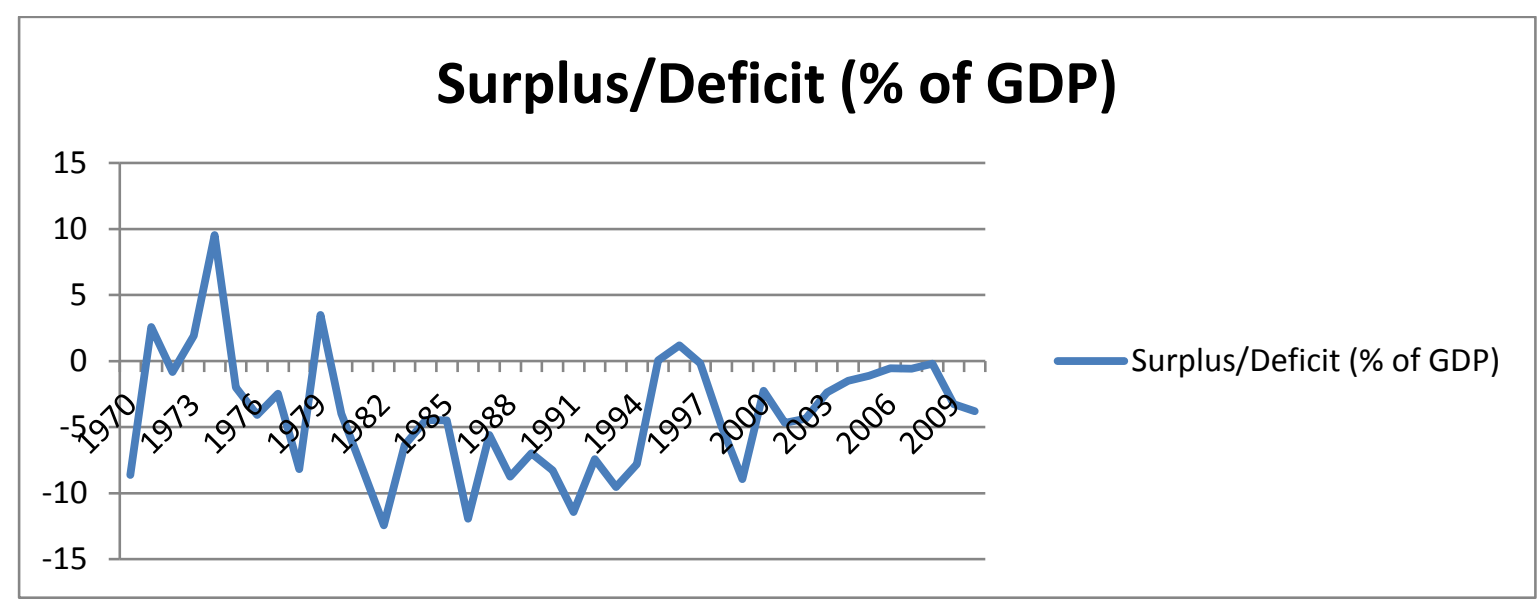

Data Source: Central Bank of Nigeria Statistical Bulletin, 2010 Edition. 
Figure 2:Nominal GDP Growth Rate and Fiscal Surplus/Deficit in Nigeria (1970-2010)

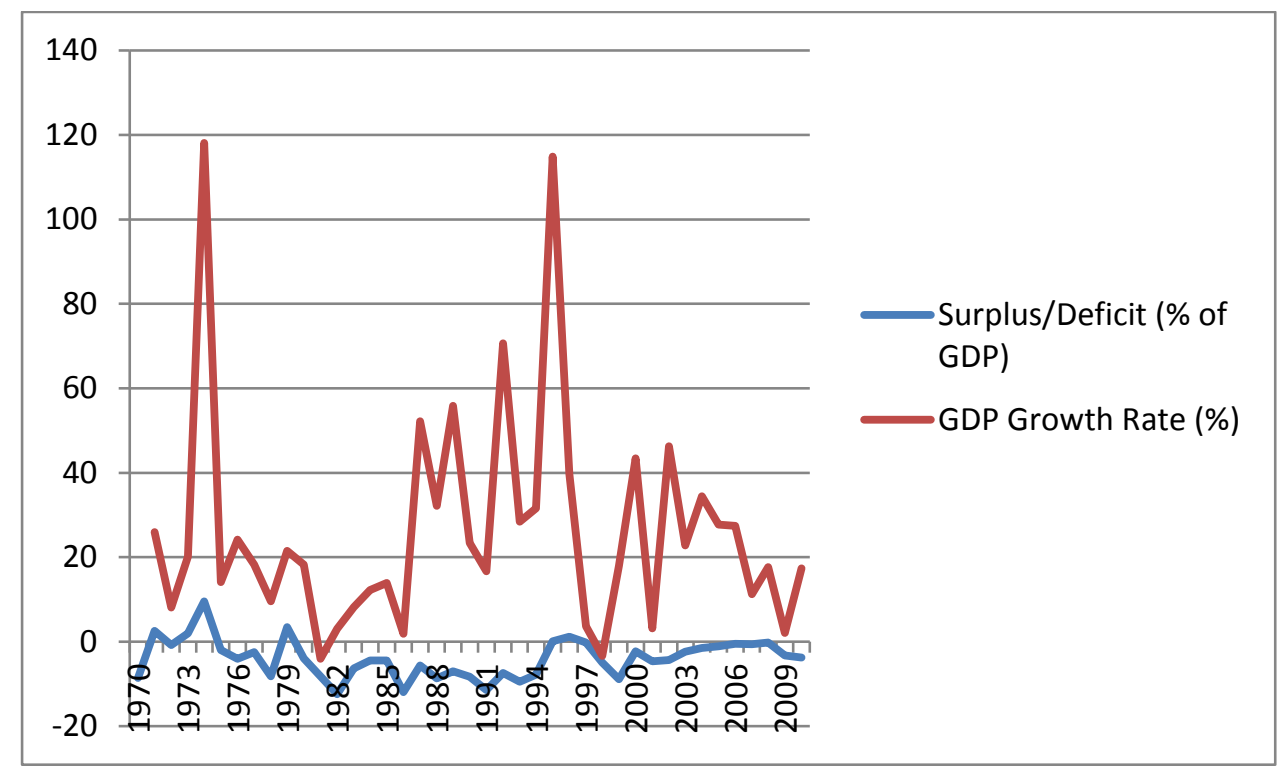

Data Source: Central Bank of Nigeria Statistical Bulletin, 2010 Edition.

\section{Monetary Policy in Nigeria}

The Central Bank of Nigeria (CBN), headed by a Governor, is the main authority in charge of monetary policy in Nigeria, with legal authority over other banks. The Bank came into being in 1959, deriving its power from the Central Bank Act of 1958, which has different amended versions (CBN, 2015). The earlier Act of the Bank was replaced by the CBN Act of 2007. The operations of the Bank have been based on the framework created by the Acts. The operations reflect the relationships of the Bank with the government, other banks in the country, and the economy as a whole. Discussions of the key features of the operations are done as follows.

\subsection{Central Bank Independence}

According to CBN (2015), the CBN Act of 2007 gives the Bank full independence compared to the limited autonomy of the previous Act. However, the full independence is practically in terms of the Bank's power to use monetary instruments. That is, the independence may be termed instrument independence, as distict from goal independence (Ojo, 2013). Crowe and Meade (2008) distinguish between the two types of independece, based on the works of Debelle and Fischer (1995) and Fischer (1995).

Instrument independence implies that a central bank is legally free to use monetary policy instruments to achieve the goals set by a higher authority, which is usually the government.On the other hand, goal independence gives the bank the power to set monetary policy objectives. Therefore, based on the nature of the independence of the CBN, it is subject to the Nigerian federal government in some way, which may give room for political interference in the operations of the Bank and affect its performance. For example, such political interference may affect policy coordination between the CBN and the fiscal authority.

\subsection{Implicit Inflation Targeting}

The main objectives that the CBN pursues as stated in the CBN Act of 2007 (Federal Republic of Nigeria Official Gazatte, 2007) are: 
(a) Monetary and price stability.

(b) Provision of legal tender currency.

(c) Management of external reserves to protect the international value of the currency.

(d) Fostering a sound financial system in the country.

(e) Serving as the banker of the Federal Government, and providing economic and financial advice to the government.

A key feature of the 2007 Act distiguishing it from the 1958 Act and its amendments is that it has price stability explicitly stated as one of the objectives of the Bank (Ojo, 2013). Achieving low inflation gradually became the focus of the CBN since the introduction of the $2007 \mathrm{Act}$, with the interest rate being the main policy instrument (Ojo, 2013; Nnanna, 2001; Chibundu, 2009), which is consistent with the policy implications of the New Consesus Macroeconomics (NCM) (Arestis, 2009).

Unlike advanced countries like New Zealand, Canada, and United Kingdom; and emerging markets like Brazil, Chile, and South Africa that have formerly adopted the Inflation Targeting (IT) policy, Nigeria only adopts the partial dimension of the policy. Economies like the US, the Euro Area, Japan, and Switzerland also adopt some of the features of the IT, and like Nigeria the economies are not classified as IT economies in the literature (Roger, 2010).

A key element of the IT framework is that the central bank of an economy directly and explicitly announces a particular numerical value of the inflation target as the primary and only goal of monetary policy, with inflation being the only monetary variable for which a target is announced (IMF, 2006; Ojo, 2013; Roger, 2010). Besides, it is also necessary in formal inflation targeting that inflation forecasts are obtained and published to serve as guides regarding possible inflation pressures.

The CBN targets "single digit" inflation, using market-based instruments, particularly the interest rate, to achieve the "inflation target," while pursuing the achievement of other monetary policy objectives, reflecting the indirect and implicit form of the policy. That is, the country's inflation target is "single digit inflation" and price stability is not explicitly the priority among the five objectives of the CBN stated above.

\subsection{Interest Rate as the Main Policy Instrument}

As indicated earlier, the interest rate is the main monetary policy instrument of the CBN in achieving the objectives. The dynamics through which the instrument works is that a central interest rate serves as the anchor for the other rates, so that variations in the anchor rate initiates desired policy changes in the other rates and the system as a whole. The interest rates currently used in monetary policy by the CBN include: interbank discount rate, Treasury Bill rate, saving deposit rate, fixed deposit rate, lending rate, and Monetary Policy Rate (MPR), with the MPR serving as the anchor rate.

The MPR was introduced in 2006 to replace the Minimum Rediscount Rate (MRR) which was the initial anchor rate. The MRR was replaced because it was not effective in anchoring other rates, which made changes in it to have insignificant impact on the broad macroeconomy (Ononugbo, 2012). There has been improvement in the performance of monetary policy since the introduction of the MPR, particularly in terms of inflation rate (Mordi and Adebiyi, 2014), which is a main objective of the policy. Figure 3 below displays the average inflation rates in Nigeria before and after the introduction of the MPR. 
Figure 3: Average Inflation Rates in Nigeria

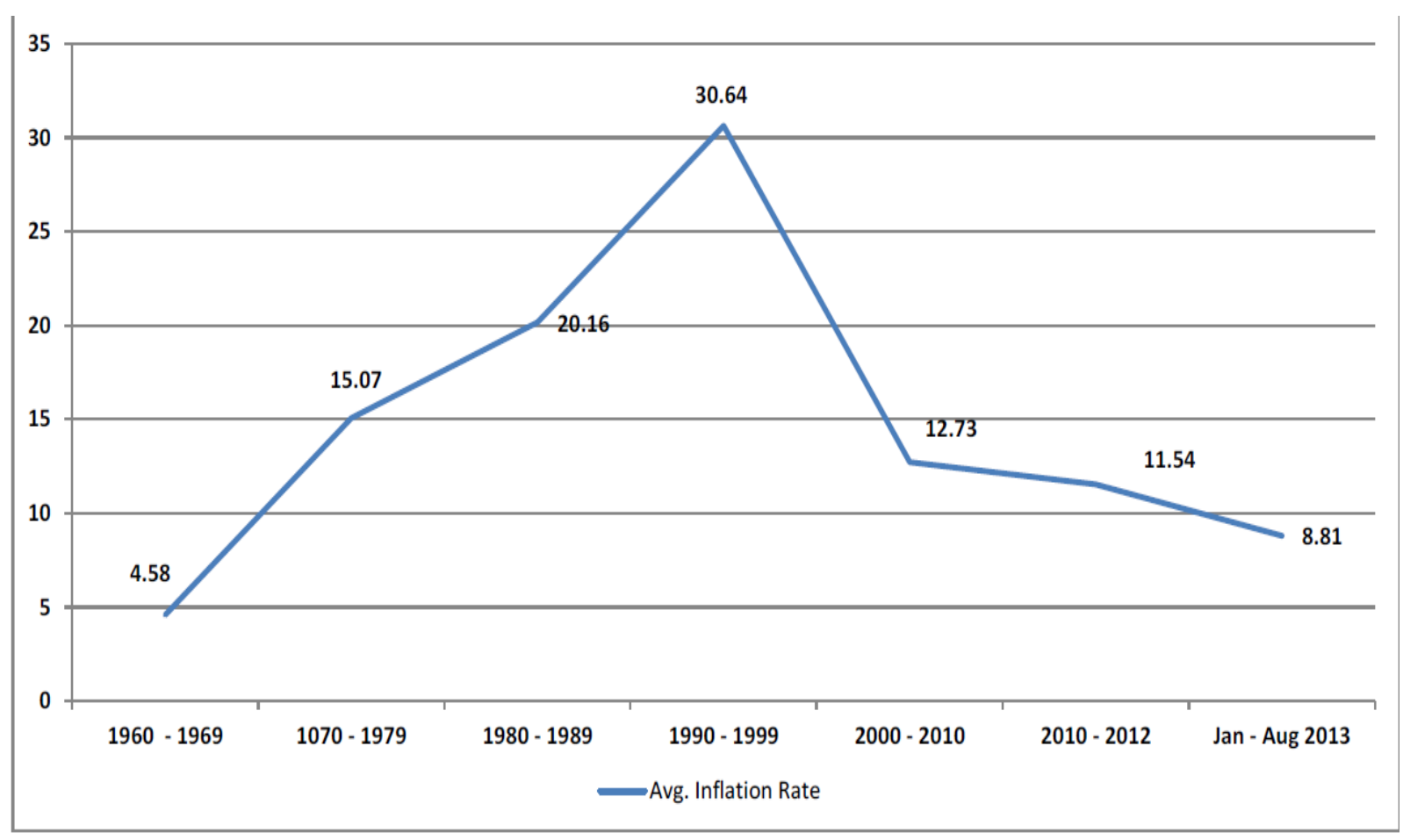

Source: Mordi and Adebiyi, 2014.

A plausible factor of the success of the MPR is the market-based or indirect monetary policy approach under which the interest rate works. The approach has been the method of monetary policy adopted by the CBN since 1993. The market-based method of monetary policy is generally regarded to be the most effective approach. For example, direct monetary instruments like administrative control of interest rates may lead to inefficient resource allocation in the economy.

\subsection{Monetary Policy Frameworks in Nigeria}

Generally, the phases of monetary policy approaches in Nigeria may be broadly divided into two, namely the exchange rate targeting phase (1959-1973) and the monetary targeting phase (1974-date), with the latter having direct (1974-1992) and market-based monetary targeting (1993-date) subphases (see for examples, Chibundu, 2009; Nnanna, 2001; Mordi and Adebiyi, 2014). The exchange rate targeting and direct monetary targeting frameworks involved administrative determination of monetary policy variables.

Exchange rate targeting started with fixing the exchange rate between the Nigerian currency and the British currency, while the direct monetary targeting involved the CBN setting the interets rate, identifying priority sectors of the economy, and directing banks on the allocation of credit to the sectors accordingly. Monetary aggregates were controlled through these processes. However, under the indirect monetary targeting, tools like the Open Market Operation (OMO) are employed to achieve the targets of monetary aggregates, which are determined in line with the general macoeconomic policies of the country.

Again, in terms of low inflation as a key monetary policy objective, monetary policy under the indirect monetary targeting regime has perfomed well on average, with headline inflation falling from over 70\% in 1996 to below 10\% in August 2013, as shown in Figure 4 below (Mordi and Adebiyi, 2014). Besides, according to these authors, real growth under the regime rose from about $0.8 \%$ in 1994 to about $6.6 \%$ in 2012, as shown in Figure 5 below. 
Figure 4: Headline Inflation under Different Monetary Regimes in Nigeria

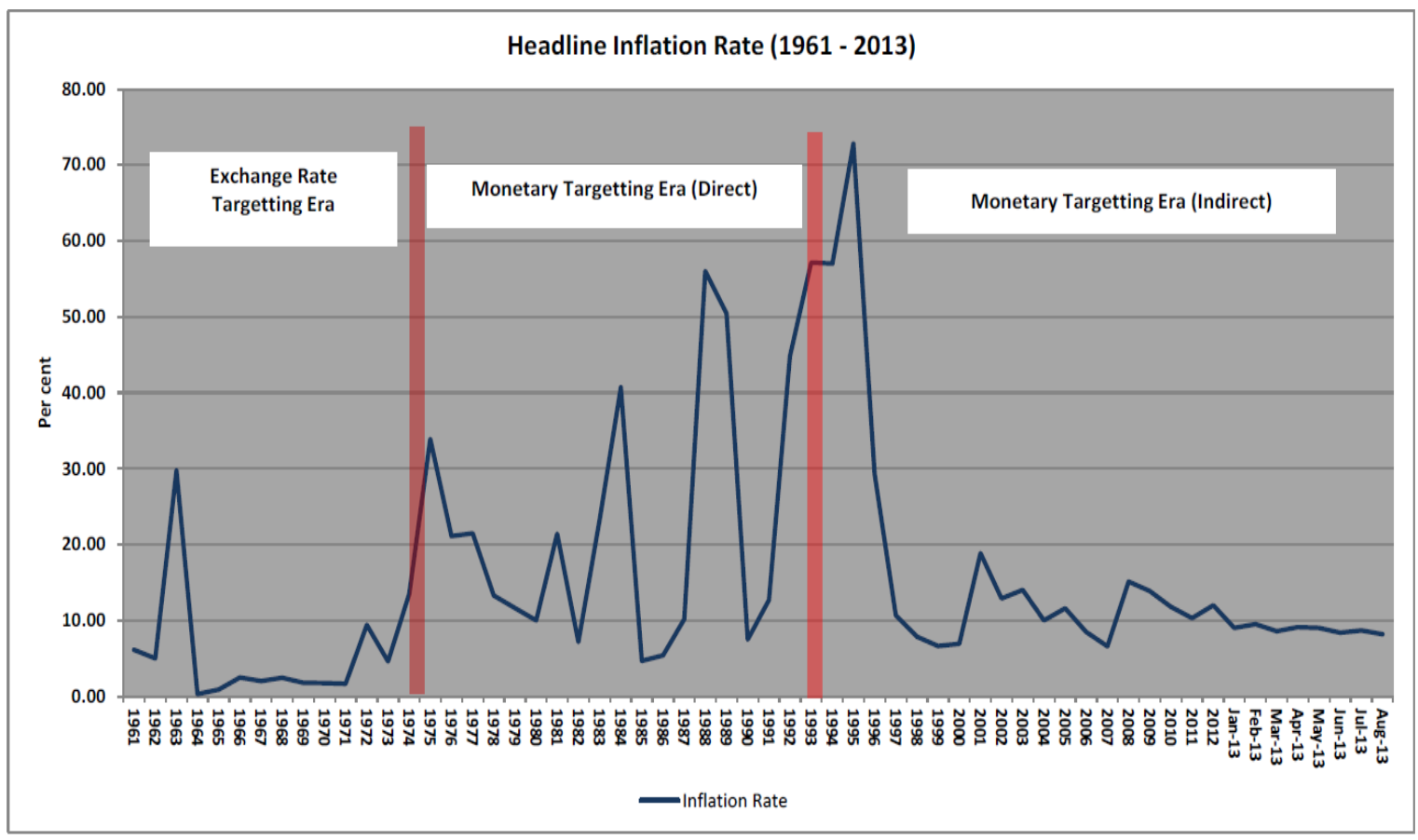

Source: Mordi and Adebiyi, 2014.

Figure 5: Real GDP Growth under Different Monetary Regimes in Nigeria

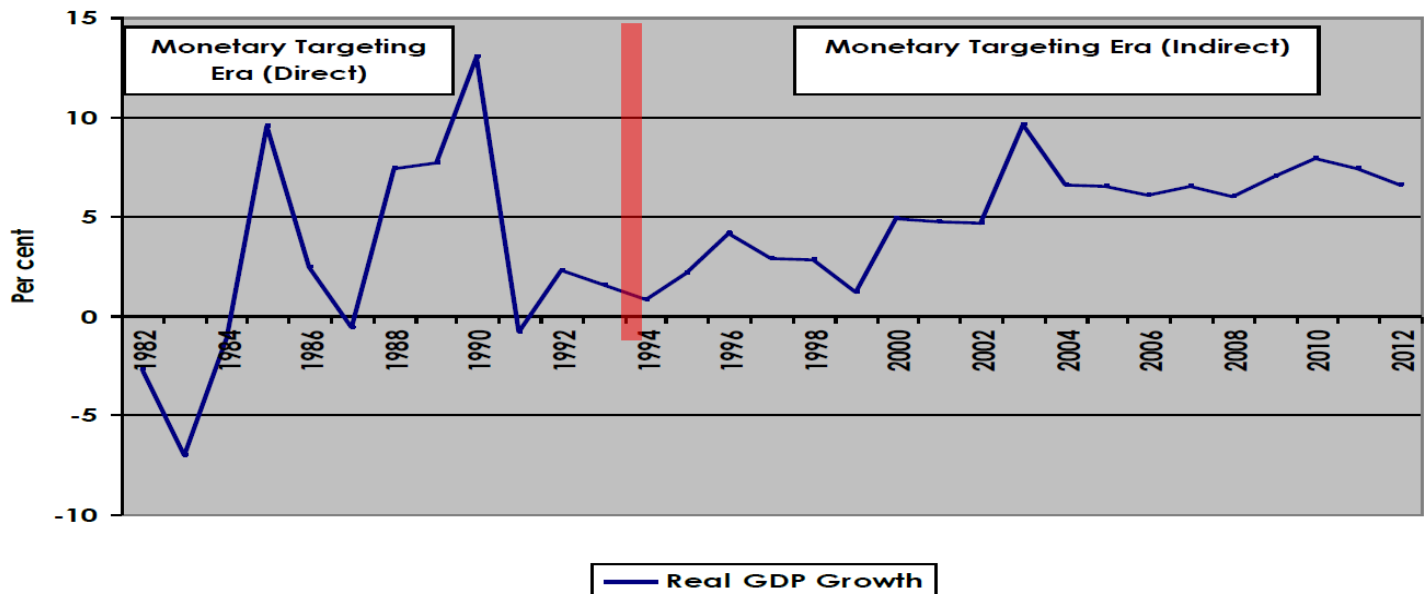

Source: Mordi and Adebiyi, 2014.

\section{Nigeria's Openness and Globalization: Implications for the Performance of Fiscal and Monetary Policies}

Nigeria's degree of openness and globalization is relatively high. Obadan (2008) notes that the level of the country's trade openness is high, even compared to that of some industrial economies. Nigeria's high openness is not only in terms of trade, as shown in Figure 6 below which indicates openness with respect to trade and other forms of cross-country flows. ${ }^{3}$

\footnotetext{
${ }^{3}$ The degree of openness of the figure is defined as the aggregated percentage share of the flows in the GDPs of the considered countries. The flows consist of trade (\% of GDP); foreign direct investment (FDI) and stocks (\% of GDP); portfolio investment ( $\%$ of GDP); and income payments to foreign nationals (\% of GDP).
} 
Figure 6: The Degrees of Openness in Nigeria and Selected Developed

\section{Countries (1970-2010)}

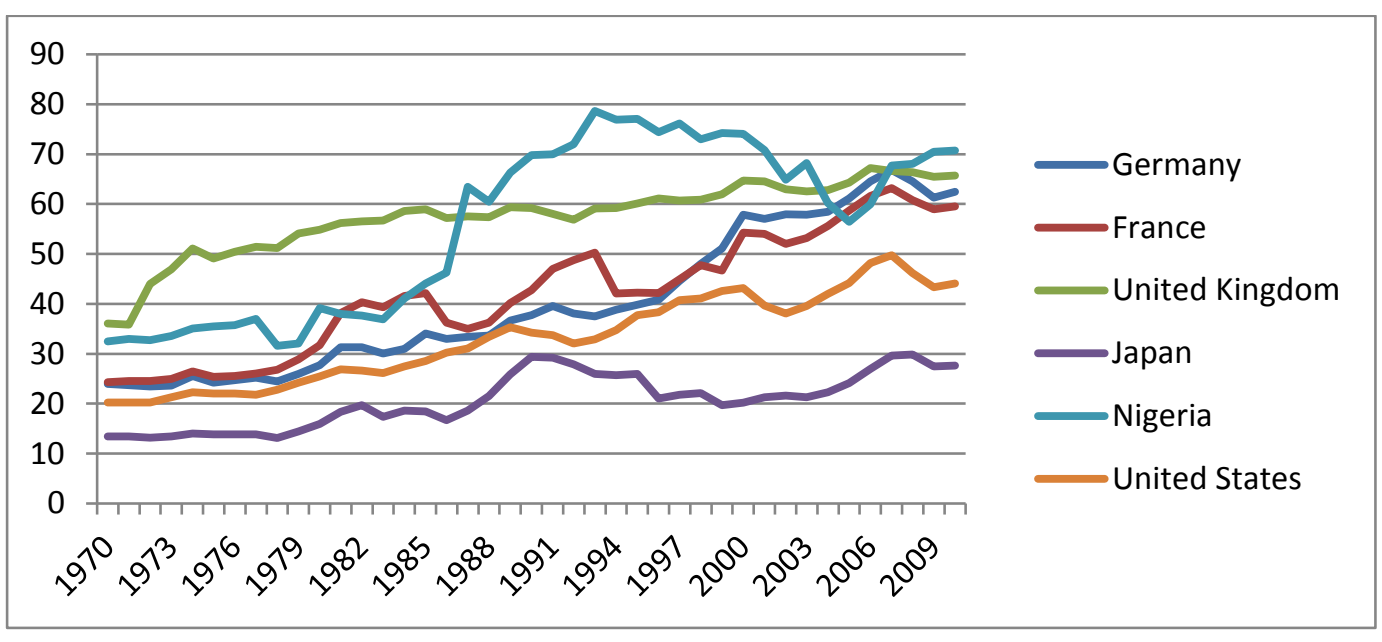

Source of Data: KOF Swiss Economic Institute (www.kof.ethz.ch).

Regarding globalization, Nigeria is ranked 81st in 2012 and 67th in 2013 in the world globalization ranking, based on the evaluation of 208 and 207 economies respectively (KOF Swiss Economic Institute, 2013, www.kof.ethz.ch). The globalization ranking is done annually based on an index that is computed by using economic, social, and political factors that affect the global integration of the economies evaluated.

Nigeria's high degree of openness and globalization has implications for the performance of fiscal and monetary policies. For example, due to high level of oil dependency, the volatility of oil price is usually transmitted via the channel of oil revenue into the country, leading to volatility in the fiscal sector and the broad macroeconomy (Okonjo-Iweala and Osafo-Kwaako, 2007; Okonjo-Iweala, 2008). Therefore, the high degree of openness and globalization of the country implies increased likelihood of hindered fiscal policy performance, as openness and globalization increase the degree of cross-border transmission of volatility.

Furthermore, high level of openness and globalization also affects the performance of monetary policy of small economies such as Nigeria, in that financial openness and globalization increase the susceptibility of such countries to international monetary policy fluctuations. According to the traditional small open economy literature (see Fleming, 1962; Mundell, 1963; Dornbusch, 1976), economies such as Nigeria are too small to individually affect the global economy, but global developments such as fluctuations in international interest rate affect their monetary policies.

\section{Conclusions and Policy Lessons}

The above review has led to some conclusions having implications relating to the performance of fiscal and monetary policies in Nigeria. The first conclusion is the dominance of fiscal deficit over fiscal surplus in the country's fiscal policy, which points to higher fiscal spending over fiscal revenue. But there is stronger fiscal discipline beginning from the 2000 s, as fiscal deficits are below $5 \%$ of GDP in this period. It would be useful to maintain the policies introduced in the 2000 s that have led to stronger fiscal discipline. Key ones among such policies are: (i) the policy involving a stabilization fund and an oil-price-based fiscal rule, both introduced in 2004 and designed to work together to limit excessive government spending via the channel of oil revenue smoothing; and (ii) the convergence 
criteria of WAMZ introduced in the early 2000s, which impose a numerical fiscal deficit limit on the proposed members of WAMZ.

The second conclusion is the procyclicality of fiscal policy, which is likely due to the diffusion of political power among the multiple authorities existing within the three tiers of government of the country. Such authorities usually compete for the "national cake" during booms, but do not compete during recessions, leading to procyclicality of fiscal policy. Since the displeasure of people about inequitable distribution of national resources is a major reason for the varying behaviours during booms and recessions, promoting equitable distribution of resources will limit procyclicality of fiscal policy in the country.

The third conclusion is that the monetary policy rate which was introduced in 2006 in the country as the anchor rate for other interest rates is effective and should be maintained. The performance of monetary policy has improved since the introduction of the monetary policy rate. For example, inflation rate has reduced significantly in the era of the monetary policy rate, which is a main objective of monetary policy in the country.

The fourth conclusion is the effectiveness of the market-based monetary policy approach introduced in the country in 1993. Compared to the period of indirect or controlled monetary policy, monetary policy has performed better under the market-based approach. In fact, the effectiveness of the monetary policy rate is largely due to the market-based framework within which it works. For example, the rigidity of the controlled monetary policy approach usually hinders automatic adjustment to shocks, which the flexibility of the market-based approach offers. It would therefore be useful to maintain the adoption of the market-based monetary policy approach.

The fifth and last conclusion is the high level of openness and globalization of the country, which affects the performance of both fiscal and monetary policies. High level of openness and globalization usually makes small open economies such as Nigeria to be vulnerable to international spillovers, particularly the ones originating from developed economies such as the USA, which consequently affects the performance of fiscal and monetary policies. It would be useful to keep the factors affecting Nigeria's openness and globalization at the optimum level. Such factors include crosscountry trade and financial flows, international political and social linkages, etc.

\section{References}

Akindele, S., Olaopa, O. and Obiyan, A. (2002). Fiscal Federalism in Nigeria: A Contemporary Review. Journal of Social Sciences, 6(3), pp. 215-235.

Arestis, P. (2009). New Consensus Macroeconomics: A Critical Appraisal. (Working Paper No. 564), University of Cambridge: The Levy Economics Institute of Bard College.

Central Bank of Nigeria (2010). Statistical Bulletin. Central Bank of Nigeria, Abuja, www.cenbank.org.

Central Bank of Nigeria, (2015). Central Bank of Nigeria, Abuja, www.cenbank.org.

Channels TV, (2012). http://www.channelstv.com/2012/03/27/excess-crude-accountfg-asks-stategovernors-for-out-of-court-settlement/. 27th March, 2012 Edition.

Chibundu, E. (2009). Monetary Policy Framework in Nigeria: Formulation and Implementation Challenges. African Institute of Applied Economics Monthly Seminar, August.

Crowe, C. and Meade, E. (2008). Central Bank Independence and Transparency: Evolution and Effectiveness. (IMF Working Paper No 119), Washington D.C.: International Monetary Fund. 
Debelle, G., Fischer, S. (1995). How independent should central banks be? In Fuhrer, J. (Eds.), Goals, Guidelines and Constraints Facing Monetary Policymakers (pp. 195-221). Boston: Federal Reserve Bank of Boston Conference Series Publication.

Dornbusch, R. (1976). Expectations and Exchange Rate Dynamics. Journal of Political Economy, 84, pp. 1161-1176.

Ekeocha, P. (2012). An Analysis of the Federal Budgeting Process in Nigeria: Implication for Institutional Reforms for Achieving Timeliness. Developing Country Series, 2(6).

Federal Government of Nigeria (2007). Official Gazette, 94(55), June.

Federal Ministry Finance (2015). Abuja, Nigeria, www.fmf.gov.ng.

Fischer, S. (1995). Central-Bank Independence Revisited. American Economic Review, 85(2), pp. 201206.

Fleming, J. M. (1962). Domestic Financial Policies Under Fixed and Under Floating Exchange Rates. (IMF Staff Papers No 9), Washington D.C.: International Monetary Fund.

IMF (2006). Inflation Targeting and the IMF. (Publication of Monetary and Financial Systems Department, Policy and Development Review Department, and Research Department of the IMF), Washington D.C.: International Monetary Fund.

Jimoh, A. (2003). Fiscal Federalism: The Nigerian Experience. Paper Delivered at the Meeting on Fiscal Policy and Growth in Africa, Fiscal Federalism, Decentralization and the Incidence of Taxation, Ad-Hoc Expert Group Meeting 7-9 October 2003, UNCC, Addis Ababa, Ethiopia, Economic Commission for Africa.

KOF Swiss Economic Institute (2013). Globalization Index. (Zurich, available at: www.kof.ethz.ch/en).

Lane, P.R., (2003). The Cyclical Behaviour of Fiscal Policy: Evidence from the OECD. Journal of Public Economics, 87, pp. 2661-2675.

Lane, P.R., Tornell, A. (1998). Why aren't Savings Rates in Latin America Procyclical? Journal of Development Economics, 57, pp. 185- 199.

Lukpata, V. (2013). Revenue Allocation Formulae in Nigeria: A Continuous Search. International Journal of Public Administration and Management Research, 2(1), October.

Mordi, C., and Adebiyi, A. (2014). The Effect of Monetary Policy on Prices in Nigeria: A Factor Augmented Vector Autoregressive (FAVAR) Modelling Approach. Paper Presented at the Centre for the Study of African Economies (CSAE) Conference, Department of Economics, University of Oxford, UK.

Mundell, R. A. (1963). Capital Mobility and Stabilization Policy Under Fixed and Flexible Exchange Rates. Canadian Journal of Economics and Political Science, 29, 475-485.

Nigeria Sovereign Investment Authority, (2015). www.nsia.com.ng.

Nnanna, O.J. (2001). Monetary Policy Framework in Africa: The Nigerian Experience. Conference Paper on the Monetary Policy Framework in Africa of Reserve Bank of South Africa. 
Obadan, M. I. (2008). Economic Globalization, Markets and National Development: How Sensibly Do the Poor Countries (Nigeria Included) Stand? 98th Inaugural Lecture Series, University of Benin, Nigeria.

Ojo M.O. (2013). Transition to Full-Fledged Inflation Targeting: A Proposed Programme for Implementation by the Central Bank of Nigeria (CBN). (CBN Occasional Paper No. 44), Abuja: Central Bank of Nigeria.

Okonjo-Iweala, N. and Osafo-Kwaako, P. (2007). Nigeria's Economic Reforms: Progress and Challenges., Washington DC: The Brookings Institution.

Okonjo-Iweala, N. (2008). Point of View: Nigeria's Shot at Redemption. Finance and Development. 45(5), December.

Ononugbo, M., C. (2012). Monetary Policy in Developing Countries: The Case of Nigeria. (Doctoral Thesis, University of Leeds, UK). Available at http://etheses.whiterose.ac.uk.

Revenue Mobilization, Allocation, and Fiscal Commission (RMAFC). (2015). http://www.rmafc.gov.ng/.

Roger, S. (2010). Inflation Targeting Turns 20. Finance and Development, 47(1), March.

Salami, A. (2011). Taxation, Revenue Allocation and Fiscal Federalism in Nigeria: Issues, Challenges and Policy Options. Economic Annals, 56(189), April-June.

Sovereign Wealth Fund Institute, (2015). http://www.swfinstitute.org/sovereign-wealth-fund-rankings/.

Talvi, E, and Vegh, C. (2005). Tax Base Variability and Procyclical Fiscal Policy in Developing Countries. Journal of Development Economics 78, pp. 156- 190.

THISDAYLIVE Newspaper. (2014). http://www.thisdaylive.com/articles/court-dismisses-gbajabiamilaothers-suit-on-excess-crude-account/193830/, 12th November. 